\title{
Bulk Modulus-Density Systematics ${ }^{1}$
}

\author{
Don L. Anderson \\ Seismological Laboratory, California Institute of Technology \\ Pasadena, California 91109
}

\begin{abstract}
The elastic constants of crystals show a general tendency to increase as the mean molar volume $\langle V\rangle=\langle M\rangle / \rho$ decreases. The role of other factors, such as cation radius, crystal field effects, and anion-cation coordination, can now be discussed with available elastic constant data. For a given coordination the parameter $\psi_{0}=\left(\rho_{0} /\langle M\rangle\right) \Phi_{0}{ }^{-1 / 3}$ (where $\rho_{0}$ is the zero-pressure density, $\langle M\rangle$ is the mean atomic weight, and $\Phi_{0}$ is the ratio of the zero-pressure bulk modulus to the density) decreases with increasing cation radius and with cell volume per oxygen atom unless a nonspherical transition element ion, such as $\mathrm{Fe}^{++}$, substitutes for a nontransition ion, such as $\mathrm{Mg}^{++}$. The calcium effect discovered by $\mathrm{G}$. Simmons is a special case of the cation radius effect. The elastic ratio $\Phi_{0}$ for complex oxides is approximately a molar average of the $\Phi_{0}$ of the component simple oxides. For silicates it appears that an empirical table of $\Phi_{0}\left(\mathrm{SiO}_{2}\right)$ can be constructed for various mineral groups. Tentatively, $\Phi_{0}\left(\mathrm{SiO}_{2}\right)$ is roughly that of $\alpha$ quartz for the feldspars, $\beta$ quartz for olivines and pyroxenes, coesite for garnets, and stishovite for spinels.
\end{abstract}

\section{INTRODUCTION}

The elastic properties of minerals depend on a variety of parameters including bonding type, crystal structure, cation-anion relationships, density, and atomic weight. For rocks and synthetic aggregates the presence of intercrystalline effects, cracks, and pores introduce additional complications. Because of the variety of phenomena affecting the elastic properties of solids, is is surprising that so many data can be summarized by one or two parameters.

Birch [1961], Anderson [1967a,b], Anderson and Kanamori [1968], Anderson and Nafe [1965], and Simmons [1964] have discussed relationships between elastic properties, density, and mean atomic weight. It is the purpose of this communication to discuss the effect of parameters other than the mean molar volume and, in particular, to present evidence that the cation radius affects the modulus-density relahonship in a systematic way. Nonspherical cransition elements must be treated separately and must form an important part of the present discussion. Simmons [1964] pointed out that calcium-rich rocks did not seem to fit into a

Division of Geological Sciences, California Institute of Technology Contribution 1622.

Copyright (c) 1969 by the American Geophysical Union. general scheme. Calcium has the largest ionic radius of any major rock-forming element, and one purpose of the present note is to present evidence that the cation radius affects the modulus-density relationship in a systematic way. Anderson and Kanamori [1968] introduced the parameter $\Psi_{0}=\left(\rho_{0} /\langle M\rangle\right) \Phi_{0}{ }^{-1 / 3}$ and showed that its average value was about 0.048 for common rocks and rock-forming minerals. They also showed (their Table 4), however, that $\psi_{0}$ tended to increase above this value for the denser oxides with high mean atomic weights. The exponent of $\Phi_{0}$ is also an average and is demonstrably different for different groups of compounds, but for present purposes it is convenient to keep this parameter fixed and to investigate the behavior of $\psi_{0}$.

\section{Cation Radius and Coordination Effects}

Figure 1 is a plot of $\psi_{0}$ versus the radius of the largest cation and, in the insert, $\psi_{0}$ versus the cell volume per oxygen atom. The parameters on the lines are cation-anion coordination numbers, and the number in brackets by the compounds is the packing index of Fairbairn [1943], which is equal to $10 \times\left(V_{\text {ions }} / V_{\text {cen } 1}\right)$. The solid lines join compounds having the same coordination; the dashed lines join end members of solid solution series involving $\mathrm{Fe}^{++}$substitution for $\mathrm{Mg}^{++*}$. 


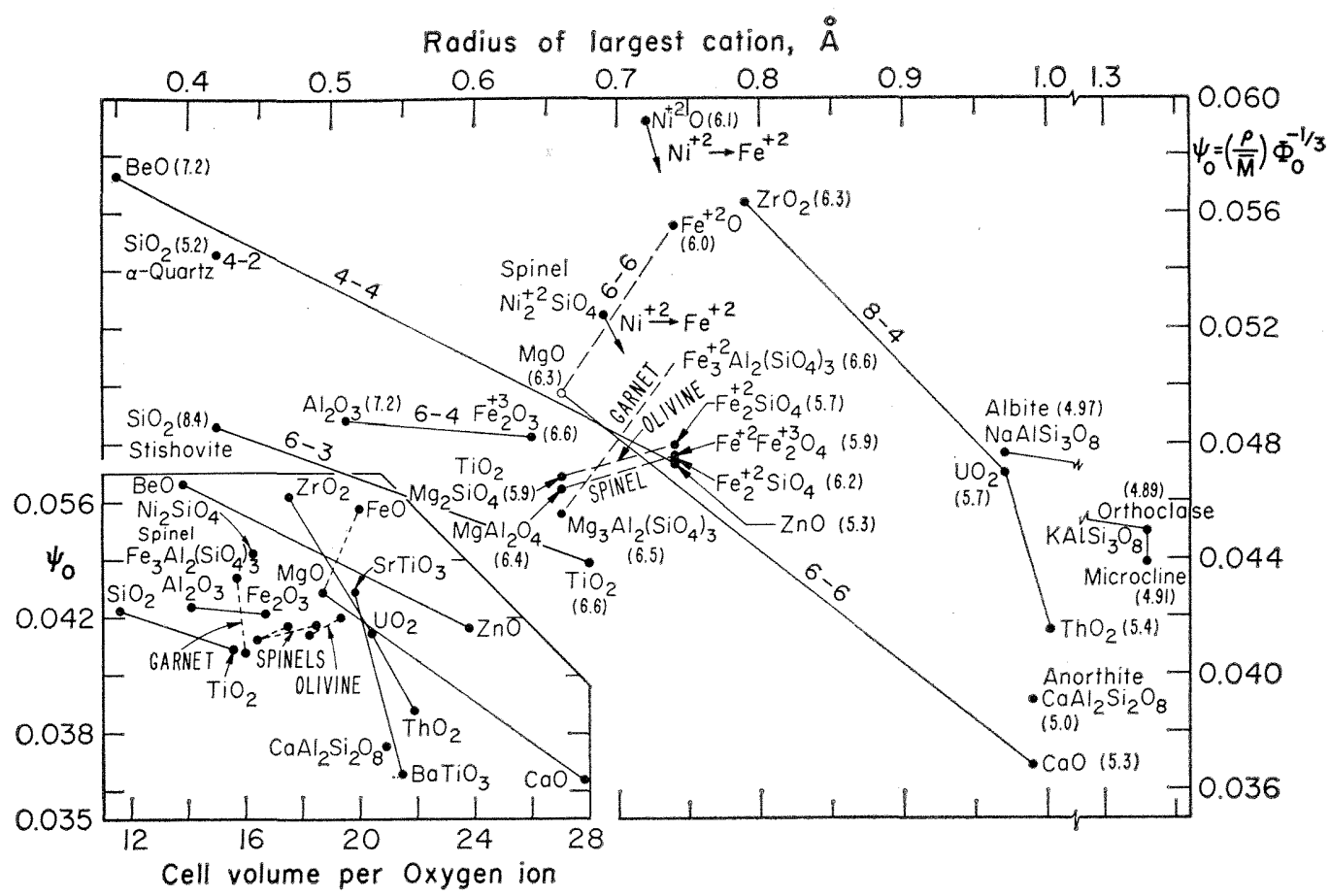

Fig. 1. $\psi_{0}$ versus radius of largest cation and (insert) versus cell volume per oxygen ion. Solid lines are isostructural joins when no nonspherical transition element is involved. Dashed lines are isostructural joins where $\mathrm{Fe}^{+t}$ replaces $\mathrm{Mg}^{+*}$. Packing indices are shown in parentheses. Coordinations are given above the lines.

In general, for a given coordination, $\rho_{0}$ and $\langle M\rangle$ increase as the size of the cation increases and the ratio $\rho_{0} /\langle M\rangle$ decreases. Since $\Phi_{0}$ also decreases as the cation radius increases, the general downward trend of the solid curves is due to the decrease of $\rho_{0} /\langle M\rangle$. Note that the packing index decreases as the cation radius increases, which indicates that the smaller cations can be more efficiently packed among the oxygen ions. When a nonspherical transition ion, such as $\mathrm{Fe}^{++}$or $\mathrm{Ni}^{++4}$, substitutes for a nontransition ion such as $\mathrm{Mg}^{++}$, there is very little change in the volume of the unit cell so that the ratio $\rho_{0} /\langle M\rangle$ does not change greatly. The seismic parameter $\Phi_{0}$ decreases, however, and, in general, the bulk modulus $K=\rho_{0} \Phi_{0}$ also decreases upon such a substitution. The net effect is an increase in $\psi_{0}$. Notice that $\mathrm{BeO}$ and $\mathrm{CaO}$ are opposite extremes of the cation radius effect.

The same trend is seen in the insert where $\psi_{0}$ is plotted against the cell volume per oxygen atom. In this plot the compounds $\mathrm{ZrO}_{2}, \mathrm{UO}_{2}$, and $\mathrm{ThO}_{2}$, the only system for which there is data for more than two nontransition elements, lie on the same straight line. This implied linearity in $\psi_{0}$ versus cell volume per oxygen ion is used in a later section to estimate the $\Phi$ for $\mathrm{BaO}$ and $\mathrm{SrO}$ from the data of $\mathrm{MgO}$ and $\mathrm{CaO}$.

$\psi_{0}$ increases by about 0.001 to 0.006 from the magnesium-rich end member to the iron-rich end member. Assuming a linear relation between $\psi_{0}$ and mole fraction $\mathrm{FeO}$ implies a rate of increase of $\psi_{0}$ of $[2$ to 12$] \times 10^{-5}$ for each mole per cent increase in $\mathrm{FeO}$.

Unfortunately, nothing quantitative can be said about the effects of phase changes on $\psi_{0}$. When phase changes are involved in a material, the exponent of $\Phi_{0}$ becomes important since this is intimately related to the repulsive potential between ions. Fortunately, the range of structures and compositions likely to be important in the lower mantle $\left(\mathrm{MgO}, \mathrm{Al}_{2} \mathrm{O}_{3}\right.$, stishovite) all have $\psi_{0}$ between 0.0486 and 
0.0498 . Therefore, a value of $\psi_{0}=0.0492$ is recommended for interpreting lower mantle seismic data. The above range in $\psi_{0}$ would correspond to an uncertainty in $\rho_{0} /\langle M\rangle$ of $2.5 \%$. By using this value of $\psi_{0}$ and by taking the high-pressure form (post spinel) of $\mathrm{Mg}_{2} \mathrm{SiO}_{4}$ to have a density appropriate for a mixture of $2 \mathrm{MgO}+\mathrm{SiO}_{2}$ (stishovite), the predicted $\Phi_{0}$ for this hypothetical phase is $59.2(\mathrm{~km} / \mathrm{sec})^{2}$.

Spinels of interest in the transition region have $\psi_{0}$ 's ranging from about 0.0465 to 0.0475 , the higher values corresponding to iron-rich spinels. Unfortunately, $\mathrm{Mg}_{2} \mathrm{SiO}_{4}$ spinel has not been measured. In lieu of other information, a value of 0.0465 is recomended for use in the spinel portion of the mantle. This value for $\psi_{0}$ gives a $\Phi_{0}$ for $\mathrm{Mg}_{3} \mathrm{SiO}_{4}$ (spinel) of $54.1(\mathrm{~km} /$ sec) $)^{2}$. In a later section the corresponding $\Phi_{0}$ is estimated to be $56 \pm 10 \%$.

Ultrasonic measurements of rocks and minerals presumably from the upper mantle average about 0.0481 , and, again, when making gross interpretations of upper mantle seismic data, this value is recommended.

Crustal rocks and common crustal minerals average about 0.0453 for $\psi_{0}$. Values range from 0.0414 for anorthosite to 0.0477 for alkali feldspars.

EFFECT of $\mathrm{FeO}, \mathrm{CaO}, \mathrm{AND} \mathrm{Al}_{2} \mathrm{O}_{3}$

For geophysical purposes it is much more convenient to discuss systematics in terms of composition rather than cation radii or cell volumes. Figure 2 gives the parameter $\psi_{0}$ for various rock and mineral systems plotted versus weight per cent $\mathrm{FeO}$. The data are sparse and scattered, but there is a clear tendency of $\psi_{0}$ to increase with $\mathrm{FeO}$ content.

For spinels and olivines, $\psi_{0} \simeq 0.0463+3.5 \times$ $10^{-5} f$, where $f$ is weight per cent $\mathrm{FeO}$. For the system $\mathrm{MgO}-\mathrm{FeO}, \psi_{0} \simeq 0.048+5.8 \times 10^{-5} f$. Except for the magnesium end member, pyrope, garnets behave intermediate to the above two systems and roughly satisfy $\psi_{0} \simeq 0.0482+$ $5.7 \times 10^{-5} f$. There are inadequate data on pyroxenes, and about all that can be said is that pyroxenes containing approximately $16 \% \mathrm{FeO}$ have a $\psi_{0}$ from 0.0465 to 0.0486 .

$\mathrm{CaO}$ has the opposite effect of $\mathrm{FeO}$; an increase in $\mathrm{CaO}$ decreases $\psi_{0}$. The following tentative formulas are derived from the limited amount of data in Figure 3 :

$$
\begin{array}{ll}
\mathrm{MgO}-\mathrm{CaO} & \psi_{0}=0.0498-1.3 \times 10^{-4} c \\
\text { pyroxene } & \psi_{0}=0.0482-1.9 \times 10^{-4} c \\
\text { olivine } & \psi_{0}=0.0462-1.6 \times 10^{-4} c \\
\text { feldspar } & \psi_{0}=0.0450-2.1 \times 10^{-4} c
\end{array}
$$

where $c$ is the weight per cent $\mathrm{CaO}$.

The effect of $\mathrm{Al}_{2} \mathrm{O}_{3}$ is even harder to pin down with available data. There is, however, a clear increase in both $\mathrm{Al}_{2} \mathrm{O}_{3}$ content and $\psi_{0}$ from pyrope to spinel to corundum, although the effect is small. In terms of mole per cent $\psi_{0}=$

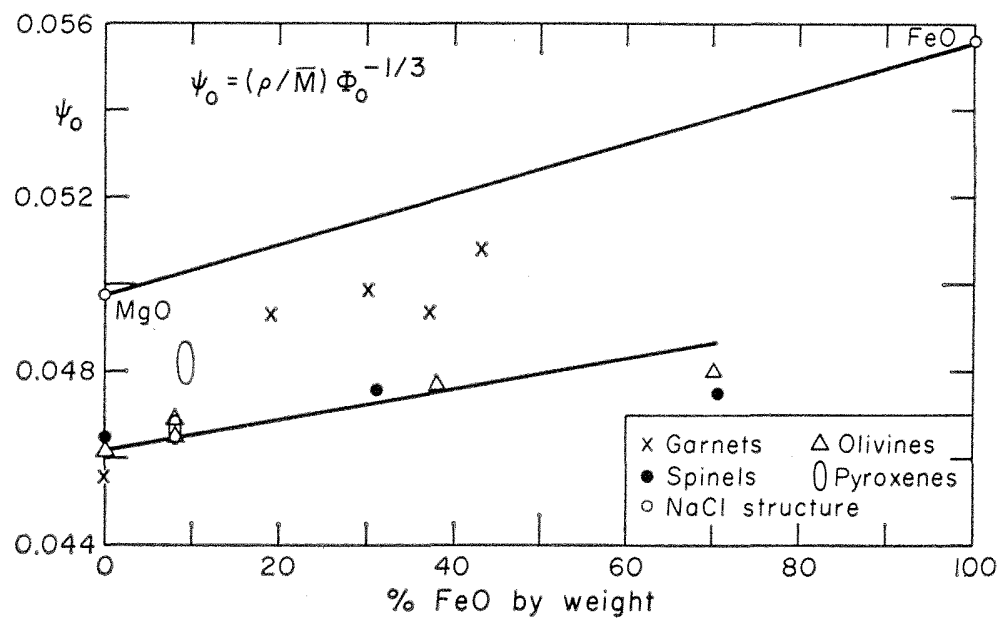

Fig. 2. Effect of iron substitution on $\psi_{0}$. 


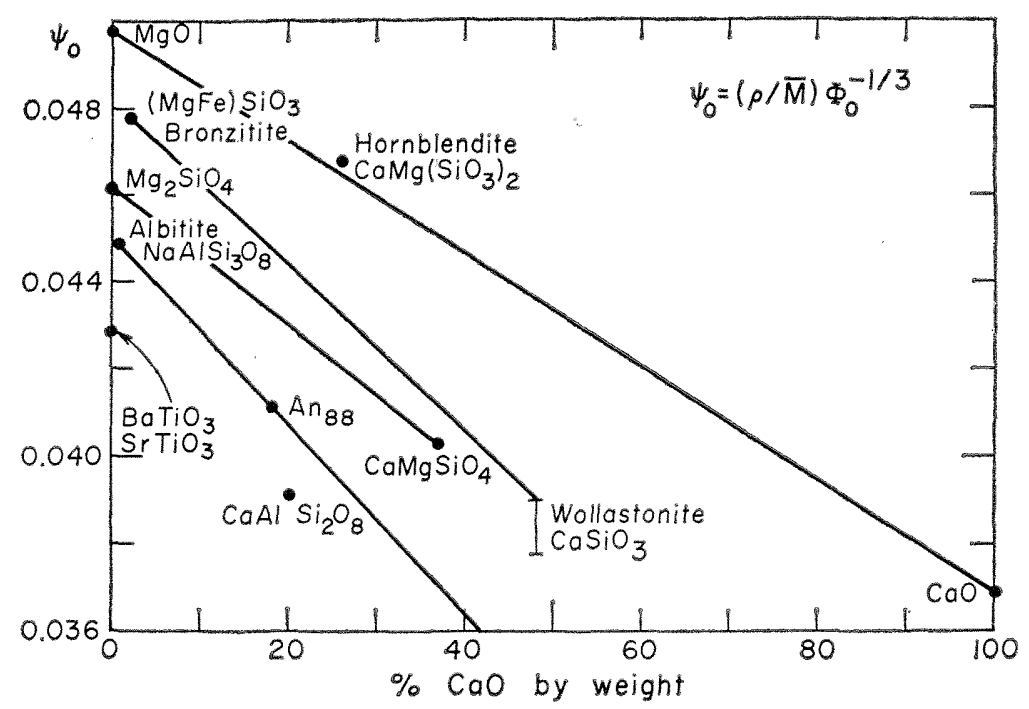

Fig. 3. Effect of calcium substitution on $\psi_{0}$.

$0.0454+3.4 \times 10^{-5} a$, where $a$ is the mole per cent $\mathrm{Al}_{2} \mathrm{O}_{3}$.

\section{ADDITIVITY OF $\Phi$}

In the course of this study it was noticed that the seismic parameter $\Phi_{0}$ for oxide compounds was very nearly the same as the molecular weighted average of the $\Phi_{0}$ 's of the component oxides. For example, $2 \Phi\left(\mathrm{MgAl}_{2} \mathrm{O}_{4}\right)=$ $\Phi(\mathrm{MgO})+\Phi\left(\mathrm{Al}_{2} \mathrm{O}_{3}\right)$. This idea is tested in Table 2 where data on oxide compounds are compared with the $\Phi$ computed from the above consideration. The number of possible comparisons is very limited since both the oxide and its components must have been measured. This limits us primarily to compounds of $\mathrm{Al}_{2} \mathrm{O}_{3}, \mathrm{MgO}, \mathrm{CaO}, \mathrm{TiO}_{2}$, and $\mathrm{Fe}_{2} \mathrm{O}_{3}$. Compounds involving $\mathrm{FeO}$ and $\mathrm{NiO}$ can be treated approximately, since crude X-ray data for the compression of these oxides are available. Unfortunately, stoichiometric $\mathrm{FeO}$ has not been measured, and there is reason to believe that the bulk modulus and $\Phi_{0}$ of the nonstoichiometric $\mathrm{FeO}$ are less than appropriate for the ideal oxide. $\mathrm{BaO}$ and $\mathrm{SrO}$ can be estimated by extrapolating $\mathrm{MgO}$ and $\mathrm{CaO}$ data under the assumption that $\psi_{0}$ is linear with mean cell volume per oxygen atom. Table 1 gives the $\Phi_{0}$ values used for the component oxides. The average error between the measured and computed $\Phi_{0}$ 's is $4 \%$. There are errors in the meas- urements of both the oxides and the oxide compounds, but it is not clear, of course, whether the true values would improve the agreement.

TABLE 1. Elastic Ratio of Simple Oxides

\begin{tabular}{|c|c|c|c|}
\hline Substance & Formula & $\begin{array}{c}\Phi, \\
(\mathrm{km} / \mathrm{sec})^{2}\end{array}$ & Method \\
\hline quartz & $\mathrm{SiO}_{2}$ & 14.2 & $u$ \\
\hline quartz & $\mathrm{SiO}_{2}$ & 22.3 & $u$ \\
\hline Coesite & $\mathrm{SiO}_{2}$ & $45 \pm 7$ & $\mathrm{x}$ \\
\hline tishovite & $\mathrm{SiO}_{2}^{4}$ & 85.4 & $\$$ \\
\hline ericlase & $\mathrm{MgO}$ & 45.3 & $u$ \\
\hline Vustite & ' $\mathrm{FeO}^{\prime}$ & 26.8 & $x$ \\
\hline Sromellite & $\mathrm{BeO}$ & 73.2 & $u$ \\
\hline ime & $\mathrm{CaO}$ & 32.2 & $u$ \\
\hline- & $\mathrm{BaO}$ & 12.9 & ex \\
\hline- & $\mathrm{SrO}$ & 20.4 & ex \\
\hline Baddeleyite & $\mathrm{ZrO}_{2}$ & 14.4 & $u$ \\
\hline Bunsenite & $\mathrm{NiO}$ & 29.2 & $\mathrm{x}$ \\
\hline Manganosite & $\mathrm{MnO}$ & 26.8 & $x$ \\
\hline Tematite & $\mathrm{Fe}_{2} \mathrm{O}_{3}$ & 39.3 & $u$ \\
\hline Corundum & $\mathrm{Al}_{2} \mathrm{O}_{3}$ & 63.5 & $u$ \\
\hline skolaite & $\mathrm{Cr}_{2} \mathrm{O}_{3}$ & 42.8 & $\mathrm{u}$ \\
\hline
\end{tabular}

Notes. $\mathrm{u}=$ ultrasonic, $\mathrm{x}=\mathrm{X}$-ray compression; $\mathrm{s}=$ shock wave; $\mathrm{ex}=$ extrapolated.

Compiled from Anderson et al. [1968], Anderson and Liebermann [1966], Mao [1968], Drickamer et al. [1966], Anderson and Kanamori [1968], Rossi [1966], Simmons [1965], Simmons and England [1969], Ahrens et al. [1969], and personal communications from O. L. Anderson, G. Simmons, E. Schreiber, and T. Takahashi. 
TABLE 2. Elastic Ratio of Oxide Compounds

\begin{tabular}{|c|c|c|c|c|}
\hline \multirow[b]{2}{*}{ Substance } & \multirow[b]{2}{*}{ Formula } & \multicolumn{2}{|c|}{$\Phi,(\mathrm{km} / \mathrm{sec})^{2}$} & \multirow{2}{*}{$\begin{array}{c}\text { Error, } \\
\%\end{array}$} \\
\hline & & Calculated & Measured & \\
\hline Spinel & $\mathrm{MgAl}_{2} \mathrm{O}_{4}$ & 54.4 & 54.5 & -0.2 \\
\hline 'Spinel' & $\mathrm{MgO} \cdot 3.5 \mathrm{Al}_{2} \mathrm{O}_{3}$ & 59.5 & 55.9 & +6.4 \\
\hline Magnetite & $\mathrm{Fe}_{3} \mathrm{O}_{4}$ & 33.2 & 36.0 & -7.8 \\
\hline Ilmenite & $\mathrm{FeTiO}_{3}$ & 37.7 & 38.4 & -1.8 \\
\hline$(\mathrm{Al}, \mathrm{Cr})_{2} \mathrm{O}_{3}$ & 4.86 mole $\% \mathrm{Cr}_{2} \mathrm{O}_{3}$ & 62.5 & 61.7 & +1.3 \\
\hline$(\mathrm{Al}, \mathrm{Cr})_{2} \mathrm{O}_{3}$ & 15.1 mole $\% \mathrm{Cr}_{2} \mathrm{O}_{3}$ & 60.4 & 60.1 & +0.5 \\
\hline$(\mathrm{Al}, \mathrm{Cr})_{2} \mathrm{O}_{3}$ & 35.8 mole $\% \mathrm{Cr}_{2} \mathrm{O}_{3}$ & 56.1 & 55.9 & +0.4 \\
\hline$(\mathrm{Al}, \mathrm{Cr})_{2} \mathrm{O}_{3}$ & 59.2 mole $\% \mathrm{Cr}_{2} \mathrm{O}_{3}$ & 51.2 & 49.6 & +3.2 \\
\hline$(\mathrm{Al}, \mathrm{Cr})_{2} \mathrm{O}_{3}$ & 78.9 mole $\% \mathrm{Cr}_{2} \mathrm{O}_{3}$ & 47.1 & 43.2 & +9.0 \\
\hline Chromite & $\mathrm{MgCr}_{2} \mathrm{O}_{4}$ & 44.0 & 45.7 & -3.3 \\
\hline Titanate & $\mathrm{BaTiO}_{3}$ & 30.7 & 27.0 & +13.7 \\
\hline Titanate & $\mathrm{SrTiO}_{3}$ & 34.4 & 34.1 & +0.9 \\
\hline \multirow{7}{*}{ Perovskite } & $\mathrm{CaTiO}_{3}$ & $40.4^{*}$ & & \\
\hline & $\mathrm{MgSiO}_{3} \dagger$ & $65.4^{*}$ & & \\
\hline & $\mathrm{FeSiO}_{3} \uparrow$ & $56.9^{*}$ & & \\
\hline & $\mathrm{Mg}_{2} \mathrm{SiO}_{4}+$ & $58.6^{*}$ & & \\
\hline & $\mathrm{Fe}_{2} \mathrm{SiO}_{4}+$ & $47.3^{*}$ & & \\
\hline & $\mathrm{Mg}_{3} \mathrm{Al}_{2}\left(\mathrm{SiO}_{4}\right)_{3} \uparrow$ & $65.0^{*}$ & & \\
\hline & $\mathrm{Fe}_{3} \mathrm{Al}_{2}\left(\mathrm{SiO}_{4}\right)_{3} \uparrow$ & $57.8^{*}$ & & \\
\hline
\end{tabular}

Note. Data taken from compilations given in note for Table 1 plus McQueen et al. [1964], Rossi [1966], Lewis [1966], and Liu et al. [1969].

* Predictions.

$\uparrow$ Ultrahigh pressure phases, i.e. post spinel, etc.; $\mathrm{SiO}_{2}$ taken as stishovite.

The agreement between the calculated and measured properties of compounds involving FeO would be greatly improved if stoichiometric Feo had a $\Phi_{0}$ of about $30(\mathrm{~km} / \mathrm{sec})^{2}$. In any event, for the limited data available, it is certainly true that the $\Phi_{0}$ for double oxides is bracketed by the $\Phi_{0}$ 's of the individual com. ponent oxides and is roughly a molecular average of the $\Phi_{0}$ 's of the component oxides. Assuming that the $\Phi_{0}$ 's are additive, the seismic parameter is calculated for hypothetical highpressure phase of olivines, pyroxenes, and garnets by assuming that the $\mathrm{SiO}_{2}$ component has a $\Phi_{0}$ appropriate for stishovite, i.e. 85.4 $(\mathrm{km} / \mathrm{sec})^{2}$. The $\Phi_{0}$ of the lower mantle at standard conditions has been estimated from extrapolation of seismic data [Anderson and Jordan, $1969]$ to lie between 58.8 and $61.3(\mathrm{~km} / \mathrm{sec})^{2}$. For a predominately ferromagnesium mantle this estimation would imply 12 to 16 mole per cent FeO, substantially higher than thought appropriate for the upper mantle. Even more FeO is implied if the high-pressure forms of pyroxene and garnet are significant fractions of the lower mantle. The estimated range of zeropressure, low-temperature densities in the lower mantle is from 4.16 to $4.30 \mathrm{~g} / \mathrm{cm}^{3}$. This value, for a predominately $(\mathrm{Mg}, \mathrm{Fe}){ }_{2} \mathrm{SiO}_{4}$ mantle, implies a range of 10 to 15 mole per cent $\mathrm{Fe}_{2} \mathrm{SiO}_{4}$, in agreement with the above estimates. If the lower mantle were predominately garnet and/or pyroxene in their high-pressure phases, the seismic data indicates that they would be more iron rich than the olivine would be if the lower mantle were predominately olivine. Both pyroxenes and garnets are much richer in $\mathrm{SiO}_{2}$ $(0.50$ and 0.43 mole fraction, respectively) than are olivines (0.33 mole fraction). The density and $\Phi_{0}$ of the lower mantle are compatible with a range in $\mathrm{SiO}_{2}$ of 39 to 46 mole per cent.

The approach used above for calculating the elastic ratio $\Phi_{0}$ for oxides, even if valid, cannot be applied in a straightforward manner to silicates because of the many polymorphs of $\mathrm{SiO}_{2}$. We can reverse the procedure, however, and use elastic constant data from silicates to estimates the $\Phi_{0}$ of the $\mathrm{SiO}_{2}$ component. Hopefully, the $\Phi_{0}\left(\mathrm{SiO}_{2}\right)$ so determined will show some con- 
TABLE 3. Elastic Ratios of Silicates and Implied Elastic Ratio of $\mathrm{SiO}_{2}$ Assuming Molar Addivity of $\Phi$

\begin{tabular}{|c|c|c|}
\hline Substanc & Idealized Formula & $\begin{array}{c}\Phi, \\
(\mathrm{km} / \mathrm{sec})^{2}\end{array}$ \\
\hline
\end{tabular}

\begin{tabular}{|c|c|c|c|c|}
\hline \multicolumn{5}{|c|}{ Group 1} \\
\hline Forsterite & $\mathrm{Mg}_{2} \mathrm{SiO}_{4}$ & 40 & 31 & Verma [1960] Single crystal \\
\hline Forsterite & $\mathrm{Mg}_{2} \mathrm{SiO}_{4}$ & 40 & 29 & $\begin{array}{l}\sim 3 \% \mathrm{BaAl}_{2} \mathrm{Si}_{2} \mathrm{O}_{8}, \text { Soga and } \\
\quad \text { Anderson }[1967]\end{array}$ \\
\hline Fayalite & $\mathrm{Fe}_{2} \mathrm{SiO}_{4}$ & $38 \pm 3$ & $24 \pm 10$ & $*$ \\
\hline Steatite & $\mathrm{MgSiO}_{3}$ & 70 & 20 & $\begin{array}{l}\sim 5 \% \mathrm{BaAl}_{2} \mathrm{Si}_{2} \mathrm{O}_{8} \text { Soga and } \\
\quad \text { Anderson }[1967]\end{array}$ \\
\hline Wollastonite & $\mathrm{CaSiO}_{3}$ & 28 & 24. & * \\
\hline Anorthite & $\mathrm{CaAl}_{2}\left(\mathrm{SiO}_{4}\right)_{2}$ & 36 & 24 & * \\
\hline Diopside & $\mathrm{CaMg}\left(\mathrm{SiO}_{3}\right)_{2}$ & $35 \pm 1$ & $26 \pm 2$ & $*$ \\
\hline Augite & $\mathrm{Ca}(\mathrm{Mg}, \mathrm{Fe})\left(\mathrm{SiO}_{3}\right)_{2}$ & 29 & $19+$ & FeO ignored* \\
\hline Mullite & $3 \mathrm{Al}_{2} \mathrm{O}_{3} \cdot 2 \mathrm{SiO}_{2}$ & 47 & 21 & $*$ \\
\hline Zircon & $\mathrm{ZrSiO}_{4}$ & 43 & 29 & * \\
\hline \multicolumn{5}{|c|}{ Group 2} \\
\hline Sillimanite & $\mathrm{Al}_{2} \mathrm{SiO}_{5}$ & 59 & 55 & * \\
\hline Garnet & $\mathrm{Mg}_{3} \mathrm{Al}_{2}\left(\mathrm{SiO}_{4}\right)_{3}$ & $55 \pm 3$ & $58 \pm 11$ & Liu [1968] \\
\hline Garnet & $\mathrm{Fe}_{3} \mathrm{Al}_{2}\left(\mathrm{SiO}_{4}\right)_{3}$ & $42 \pm 2$ & $50 \pm 5$ & Liu $[1968]$ \\
\hline Garnet & $3(\mathrm{Mg}, \mathrm{Fe}) \mathrm{Al}_{2}\left(\mathrm{SiO}_{4}\right)_{3}$ & 42 & $48 \pm 2$ & $2.43 \%$ FeO, Verma [1960] \\
\hline Garnet & $3(\mathrm{Mg}, \mathrm{Fe}, \mathrm{Ca}) \mathrm{Al}_{2}\left(\mathrm{SiO}_{4}\right)_{3}$ & $50 \pm 1$ & $58 \pm 3$ & $\begin{array}{c}1.05 \% \mathrm{FeO}, 0.3 \% \mathrm{CaO} \\
\text { Liu }[1968]\end{array}$ \\
\hline Garnet & $(\mathrm{MgFeMnCa})_{3}(\mathrm{Al} \mathrm{Fe})_{2}\left(\mathrm{SiO}_{4}\right)_{3}$ & 43 & 50 & Soga $[1967]$ \\
\hline Beryl & $\mathrm{Be}_{3} \mathrm{Al}_{2}\left(\mathrm{SiO}_{3}\right)_{6}$ & $55 \pm 2$ & $44 \pm 4$ & $*$ \\
\hline \multicolumn{5}{|c|}{ Group 9} \\
\hline 'Spinel' & $\mathrm{Fe}_{2} \mathrm{SiO}_{4}$ & $44 \pm 2$ & $80 \pm 10$ & Mao et al. [1969] \\
\hline 'Spinel' & $\left(\mathrm{Mg}_{0.1} \mathrm{Fe}_{0.9}\right)_{2} \mathrm{SiO}_{4}$ & $42 \pm 2$ & $70 \pm 10$ & Mao el al. [1969] \\
\hline 'Spinel' & $\left(\mathrm{Mg}_{0.2} \mathrm{Fe}_{0.8}\right)_{2} \mathrm{SiO}_{4}$ & $45 \pm 2$ & $77 \pm 10$ & Mao et al. [1969] \\
\hline 'Spinel' & $\mathrm{Ni}_{2} \mathrm{SiO}_{4}$ & $40 \pm$ & $60 \pm$ & Mao [1967] \\
\hline 'Spinel' & $\mathrm{Mg}_{2} \mathrm{SiO}_{4} \dagger$ & $56 \pm 6 \uparrow$ & & Spinel structure \\
\hline
\end{tabular}

* See notes on Tables 1 and 2.

$\dagger$ Predicted.

sistency in the various mineral groups so that they can be used empirically to estimate the $\Phi_{0}$ of unmeasured minerals. The general philosophy is the same as constructing a table of empirical ionic radii that can be used to estimate cell volumes. The results are shown in Table 3 . They divide naturally into three groups. In group 1 the $\Phi_{0}\left(\mathrm{SiO}_{2}\right)$ averages about $25(\mathrm{~km} /$ $\mathrm{sec})^{2}$. These minerals are all noncubic and have relatively open structures. The cell volumes per $\mathrm{SiO}_{2}$ are mostly greater than $65 \mathrm{~A}^{3}$, and the packing index is less than 6 . For comparison, the $\Phi_{0}$ 's for $\alpha$ and $\beta$ quartz are 14.2 and 22.3 $(\mathrm{km} / \mathrm{sec})^{2}$, respectively. In group 2 the average $\Phi_{0}\left(\mathrm{SiO}_{2}\right)$ is $52(\mathrm{~km} / \mathrm{sec})^{2}$. The $\Phi_{0}\left(\mathrm{SiO}_{2}\right)$ for coesite is $50 \pm 5$ [Bassett and Barnett, 1969]. These are closer packed, mainly cubic minerals and except for sillimanite have cell volumes per
$\mathrm{SiO}_{2}$ between 56 and $64 \mathrm{~A}^{3}$ and packing indices of about 6.5 except for beryl. Croup 3 includes only spinels, and the $\Phi_{0}\left(\mathrm{SiO}_{2}\right)$ in this group is greater than $60(\mathrm{~km} / \mathrm{sec})^{2}$. The geophysically interesting iron and magnesium spinels average about $76(\mathrm{~km} / \mathrm{sec})^{2}$ with a fairly large uncertainty because of the uncertainty in $\Phi_{0}(\mathrm{FeO})$. The $\Phi_{0}$ 's in group 3 are clearly larger, however, than for group 2. For comparison the $\Phi_{0}$ for stishovite has been estimated to be $85.4(\mathrm{~km} /$ sec) ${ }^{2}$ [Ahrens et al., 1969]. From X-ray comparison data Liu et al. [1969] and Bassett and Barnett [1969] obtain $\Phi_{0}$ for stishovite of $80 \pm$ 5 and $70 \pm 7(\mathrm{~km} / \mathrm{sec})^{2}$ (isothermal), respectively. The cell volume per $\mathrm{SiO}_{2}$ in this group falls between 52 and 70 , i.e. intermediate to the other two groups. The range is restricted to between 66 and 70 for spinels of geophysical 
interest. The packing index for spinels is about 5.9 to 6.4 .

Thus, the silicates can be differentiated into three groups on the basis of the implied $\Phi_{0}(\mathrm{SiO})_{2}$ and these $\Phi_{0}(\mathrm{SiO})_{2}$ are roughly comparable to $\Phi_{0}\left(\beta\right.$ quartz) in group $1, \Phi_{0}$ (coesite) in group 2 , and $\Phi_{0}$ (stishovite) in group 3 . The minerals in groups 2 and 3 are clearly more closely packed than those in group 1 , but other arguments must be involved to explain why the Si-O bonding in spinels is apparently stronger than in the garnets. The presence of aluminum in the minerals of group 2 is probably significant.

On the basis of the range of $\Phi_{0}\left(\mathrm{SiO}_{2}\right)$ for the spinel group the $\Phi_{0}$ for $\mathrm{Mg}_{2} \mathrm{SiO}_{4}$ spinel has been predicted to be about $56 \pm 10 \%$. This can be compared with the value $54(\mathrm{~km} / \mathrm{sec})^{2}$ used by Anderson [1967c], which was derived on other considerations. In Table 2 the $\Phi$ for the 'post spinel' form of $\mathrm{Mg}_{2} \mathrm{SiO}_{4}$ was estimated to be $58.6(\mathrm{~km} / \mathrm{sec})^{2}$. This value is much smaller than the $70(\mathrm{~km} / \mathrm{sec})^{2}$ used by Anderson [1967c] in a straightforward application of the seismic equation of state. With the recommended value for $\psi_{0}$ in a previous section for high-pressure phases, the $\Phi_{0}$ for $\mathrm{Mg}_{2} \mathrm{SiO}_{3}$ in the post spinel phase was found to be $59.2(\mathrm{~km} / \mathrm{sec})^{2}$, in good agreement with the value found above. There is, therefore, presumably only a small increase in $\Phi$ as mantle minerals collapse from the spinel to the post spinel phase near $620 \mathrm{~km}$.

It is clear that a great deal more ultrasonic and X-ray compression data on simple oxides and dense silicate minerals must be collected before the simple ideas expressed in this paper can be fully tested. For geophysical purposes we need the elastic constants of stoichiometric $\mathrm{FeO}, \mathrm{Na}_{2} \mathrm{O}$, and $\mathrm{K}_{2} \mathrm{O} . \mathrm{BaO}$ and $\mathrm{SrO}$ are important for testing the systematics. Important minerals that need investigating are $(\mathrm{Mg}, \mathrm{Fe})$ $\mathrm{SiO}_{3}$ pyroxenes, iron-rich olivines, and perovskites. Solid solution series involving $\mathrm{Mg}, \mathrm{Fe}, \mathrm{Ca}$, and Al must be studied before we fully understand the compositional systematics. Polymorphism cannot be treated adequately with available data. It is important to measure the elastic constants on several polymorphs of the same material.

The alkali feldspars are even more open packed than those minerals discussed previously. Packing indices for feldspars are typically
5 and the cell volumes per oxygen atom are typically 21 to $33 \mathrm{~A}^{3}$ compared with about 18 for olivine and pyroxene, 16 for garnets, and 16 to 18 for spinels. They have not been treated, owing to the lack of data on the alkali oxides. The low $\Phi_{0}$ 's measured on the alkali feldspars imply both that the alkali oxides, i.e., $\mathrm{Na}_{2} \mathrm{O}$, $\mathrm{K}_{2} \mathrm{O}$, must have low values for $\Phi_{6}$ and that the appropriate $\Phi_{0}$ for $\mathrm{SiO}_{2}$ must also be low. For example, if $\Phi_{0}\left(\mathrm{SiO}_{2}\right)$ for $\mathrm{NaAlSi}_{3} \mathrm{O}_{8}$ is $14.2(\mathrm{~km} /$ $\mathrm{sec})^{2}$, the value for $\alpha$ quartz, then $\Phi_{0}\left(\mathrm{Na}_{2} \mathrm{O}\right)$ is $14(\mathrm{~km} / \mathrm{sec})^{2}$. A correspondingly low value is implied for $\mathrm{K}_{2} \mathrm{O}$.

Acknowledgments. The author would like to thank Taro Takahashi, Gene Simmons, Stan Marsh, and Edward Schreiber for making available unpublished data from their laboratories. He is grateful to Ed Gaffney and Tom Ahrens for many stimulating discussions.

This research was supported by National Science Foundation grant GA 1003.

\section{REFERENCES}

Ahrens, T. J., D. L. Anderson, and A. E. Ringwood; Equation of shocked silicates and oxides, of states and crystal structures of high-pressure phases, Rev. Geophys., 7 , in press, 1969.

Anderson, D. L., A seismic equation of state, Geophys. J., 18, 9-30, 1967a.

Anderson, D. L., Latest information from seismic observations, chapt. 12, The Earth's Mantle, edited by T. F Gaskell, Academic Press, New York, $1967 b$.

Anderson, D. L., Phase changes in the upper mantle, Science, 15\%, 1165-1173, 1967c.

Anderson, D. L., and T. Jordan, The composition of the lower mantle, Phys. Earth and Planetary Interiors, in press, 1969.

Anderson, D. L., and H. Kanamori, Shock wave equations of state for rocks and minerals, $J$. Geophys. Res., 73, 6477-6502, 1968.

Anderson, O. L., and R. C. Liebermann, Sound velocities in rocks and minerals, VESIAC Stateof-the-Art Rept., 7885-4-X, Institute of Science and Technology, University of Michigan, Ann Arbor, 1966.

Anderson, O. L., and J. E. Nafe, The bulk modulus-volume relationship for oxide compounds and related geophysical problems, J. Geophys. Res., 70, 3951-3963, 1965.

Anderson, O. L., E. Schreiber, R. C. Liebermann, and N. Soga, Some elastic constant data on minerals relevant to geophysics, Rev. Geophys., 6, 491-524, 1968.

Bassett, W. A., and J. D. Barnett, Isothermal compression of stishovite and coesite to 100 kilobars by X-ray diffraction (abstract), Trans. Am. Geophys. Union, 50, 312, 1969. 
Birch, F., Composition of the earth's mantle, Geophys. J., 4, 295-311, 1961.

Drickamer, H. G., R. W. Lynch, R. L. Clendenen, and E. A. Perez-Albueme, X-ray diffraction studies of the lattice parameters of solids under very high pressure, Solid State Phys., 19, 135$228,1966$.

Fairbairn, H. W., Packing in ionic minerals, Bull. Geol. Soc. Am., 54, 1305-1374, 1943.

Lewis, M. F., Elastic constants of magnesium aluminate spinel, J. Acoust. Soc. Am., 40, 728$729,1966$.

Liu, L., Isothermal compression of magnesium garnets up to 300 kilobars and its implication to the earth's mantle, M.S. thesis, Department of Geological Sciences, University of Rochester, N. Y., 1968.

Liu, L. G., T. Takahashi, and W. A. Bassett, Compression of stishovite and magnesium ilmenite at $25^{\circ} \mathrm{C}$ (abstract), Trans. Am. Geophys. Union, 50, 312, 1969.

Mao, H.K., The pressure dependence of the lattice parameters and volume of ferromagnesian spinels, and its implications to the earth's mantle, Ph.D. thesis, University of Rochester, N.Y., 1967.

Mao, H.-K., T. Takahashi, W. A. Bassett, J. S. Weaver, and S. Akimoto, Effect of pressure and temperature on the molar volumes of wus- tite and of three $(\mathrm{Fe} \cdot \mathrm{Mg})_{2} \mathrm{SiO}_{4}$ spinel solid solutions, J. Geophys. Res., 74, 1061-1069, 1969.

McQueen, R. G., J. N. Fritz, and S. P. Marsh, On the composition of the earth's interior, $J$. Geophys. Res., 69, 2947-2966, 1964.

Rossi, L. C., The elastic properties of oxide solid solutions; The system $\mathrm{Al}_{2} \mathrm{O}_{3}-\mathrm{Cr}_{2} \mathrm{O}_{3}$, Monthly Rept. 363, S.U.N.Y. College of Ceramics, September 1966.

Simmons, G., Velocity of compressional waves in various minerals at pressures up to 10 kilobars, J. Geophys. Res., 69, 1117-1121, 1964.

Simmons, G., Single crystal elastic constants and calculated aggregate properties, J. Grad. Res. Center, 34, Southern Methodist University, Dallas, Texas, 1965.

Simmons, G., and A. W. England, Universal equations of state for oxides and silicates, in press, 1969.

Soga, N., The elastic constants of gamet under pressure and temperature, J. Geophys. Res., 72, 4227-4234, 1967.

Soga, N., and O. L. Anderson, High-temperature. elasticity and expansivity of forsterite and steatite, J. Am. Ceram. Soc., 50, 239-242, 1967.

Verma, R. K., Elasticity of some high-density crystals, J. Geophys. Res., 65, 757-766, 1960.

(Received April 1, 1969.) 